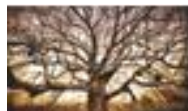 \\ AVRASYA Uluslararası Araştırmalar Dergisi Cilt:5 •Sayı:11•Temmuz 2017•Türkiye
}

\section{AZERBAYCAN TÜRK KÜLTÜRÜNDE HIDIR-NEBI BAYRAMI}

\author{
Yrd.Doç.Dr.Türkan ARIK GADIRZADE*
}

\section{ÖZ}

Türk kültüründe kendine özgü yeri olan Hıdır-Nebi, Hızır- Nebi, Hıdır-Zinde bayramı Şubat ayının 9'unda Nahçıvan bölgesinde yaşayan Azerbaycan Türkleri arasında büyük çoşku ile kutlanmaktadır. Nevruz bayramından kırk gün önce kutlanan bu bayram nesillerden nesillere miras bırakılarak günümüze kadar gelmiştir. Bayram günlerinde uygulanan adet ve inanışlar uzun dönemli halk tecrübesine dayanmakla beraber benliğinde bin yıllık tarih saklamaktadır. Hıdır- Nebi buğdayının kavrulması, çerezlerin alınması, bayram günü dileklerinin gerçek olması için uygulanan yöntemler, akşam vakti kapıya gelecek olan çocukların payının verilmesi bayramın kültürel zenginliğini göstermektedir.

Bölgede yaygın olan inanca göre bayram Hızır (a.s.) ve İlyas'ın (a.s.) bayramıdır ve onlerın şerefine kutlanmaktadır. Havaların soğuk olduğu dönemlerde bayramın kutlanması, Hızır'ın (a.s.) yardıma çağııııması ona olan ihtiyaçla alakalı olmuştur. İnanışlara göre, Hızır (a.s.) kendisi ile sıcak hava getirecek havalar az da olsa ısınacaktır. Hızır'ın (a.s.) bayram günü evlere rızık, gençlere nasip dağıtması inancı da bölgede yaygındır. Herkes rızkını ve nasibini Hızır'dan (a.s.) almak için farklı uygulamalar yapar, dileklerinin gerçek olması için dualar ederlerdi. Karşıdan gelen yılın bol bereketli olması için farklı uygulamalar yapar kendi aralarında çeşitli eğlenceler düzenleyerlerdi. Mevsimlik olarak kutlanan bu bayramla ilgili adet ve inanışlar günümüzde de devam etmektedir.

Anahtar Kelimeler: Hıdır-Nebi, Hıdırellez, Bayram, Buğday, Çerez

\section{KHIDR-NEBI HOLIDAY IN AZERBAIJJAN TURKISH CULTURE}

\section{ABSTRACT}

Khidr Nebi, Khizr Nebi, Khidr-Zinde holiday with its unique place in Turkish culture is celebrated with great enthusiasm among the Azerbaijani Turks living in the Nakhchivan region in the 9th of February. This holiday, celebrated 40 days before the Nevruz festival, has been inherited by generations of generations and has been up to daylight. The traditions and beliefs practiced during the holiday days are based on long-lived folk experience and keep a thousand years history in their own selves. Khidr-Nebi wheat roasting, nut buying, methods used to make the wishes of the holiday day true, showing the proportion of children coming to the door in the evening shows the cultural richness of the holiday.

According to the common denomination of the region, the feast is the holiday of Khizir (a.s) and Illyas (a.s) and is celebrated in their honor. The celebration of the feast during periods when the air is cold, the call for help from Khidr (a.s) has become relevant to her needs. According to beliefs, Khidr (a.s) will warm up with a little air to bring warm air with him. Khidr (a.s) on the eve of the holiday sustenance, the young people to distribute the belief that the region is widespread. Everyone has different applications to get ridiculous and grant from Khıdr (a.s), praying that their wishes are real. In order to be abundant in the coming year, they made different applications and organized various entertainments among themselves. The traditions and beliefs about this holiday which is celebrated seasonally are still going on today.

Keywords: Khidr-Nebi, Khidirellez,Holiday, Wheat, Nut

\footnotetext{
* Iğdır Üniversitesi Fen Edebiyat Fakültesi Tarih Bölümü, turkan.gadirzade@ gmail.com
} 
Büyük bir coğrafi alana yayılmış Türk halklarında yılın belirli zamanlarında mevsimlik olarak kutlanan bayramların karşılaştırmalı olarak öğrenilmesi, Türk Kültür tarihi açısından büyük önem arz etmektedir. Yapılan araştırmalar Türk halkları arasında kutlanan bayramların isimlerinin ve bayram günlerinde uygulanan adet ve inanışların bölgeler arasında benzer ve farklı şekillerde uygulandığını göstermektedir. Örneğin Azerbaycan Türkleri arasında Hıdır-Nebi adı ile bilinen bayram Anadolu Türkleri arasında Hıdırellez adı ile bilinmekte ve kutlanmaktadır. Her iki bayramın farklı tarihlerde kutlanması ve bayram günlerinde uygulanan adet ve inanışların farklılık göstermesi Türk Kültürünün zenginliği olmakla beraber her iki bayramın da çok eski dönemlerden beri Türkler arasında kutlandığını ve nesillerden nesillere miras bırakılarak günümüze kadar geldiğini ortaya koymaktadır. Bu makalede Azerbaycan Türkleri arasında büyük coşku ile kutlanan ve halk kültüründe kendine özgü yeri olan Hıdır-Nebi bayramı ve bayram günlerinde uygulanan adet ve inanışlar hakkında bilgiler verilmiştir.

Nahçıvan bölgesinde Nevruz bayramından kırk gün önce kutlanan Hıdır-Nebi bayramı; Hızır- Nebi, Hızır- İlyas, Hıdır-Zinde bayramı olarak da bilinmektedir. Azerbaycan mitolojisinde Hıdır-Nebi bayramının Hızır (a.s.) ve İlyas (a.s.) şerefine gerçekleştirilmesi ile ilgili birçok rivayetler mevcuttur (Azerbaycan Mifoloji Metnleri 1988: 67). Kaynaklarda Hızır (a.s.) ve İlyas'ın (a.s.) kardeş olmasından, Hızır'ın (a.s.) yeşilliğin, İlyas'ın (a.s.) ise suyun hamisi olmasından bahsedilir. Rivayete göre İlyas (a.s.) suyun, Hızır (a.s.) ise yeşilliğin hamisi olarak Tanrı tarafından görevlendirilir ve bu görevden dolayı birbirlerinden ayrı kalırlar (Nebiyev 1986a:59). Azerbaycan Türkeri'nin inanışlarına göre iki kardeş Nevruz Bayramından 40 gün önce insanlara rızık, bereket, dağıtmak, hastaları iyileştirmek, dileği olanların dileğini gerçekleştirmek için yeryüzünde buluşuyorlar. Bu önemli olay sebebiyle Azerbaycan'ın diğer bölgelerinde olduğu gibi Nahçıvan bölgesinde de Hızır (a.s.) ve İlyas (a.s.)'ın yeryüzünde buluşması şerefine Şubat ayının 9'unda kutlamalar düzenleyip, rızık ve bereketlerinin artması, hastalıklarının iyileşmesi için farklı uygulamalar yaparlar (Gadirzade 2006: 12). Nahçıvan'ın Kengerli ilçesi Çalhankale ve Tazekend köylerinde Hıdır- Nebi bayramı üç kere, Şubatın 5'i kışın yarısı bittiği için, Şubatın 9'u Küçük Çille'nin yarısı bittiği için, Şubatın 15'i Hızır (a.s.)'ın doğum günü olduğu için kutlanmaktadır. Halk takvimine göre kış 21 Aralık'ta başlamakta ve üç kısma bölünmektedir. Birinci kısım: Büyük Çille-kırk gün, 21 Aralık / 30 Ocak, İkinci kısım: Küçük Çille - yirmi gün, 31 Ocak / 20 Şubat, Üçüncü kısım: Çille Beçeler, Ala Çille, Boz Ay, Bayram Ayı - yirmi gün; 20 Şubat / 20 Mart olarak bilinmektedir. Derlenen bilgilere göre Küçük Çille'nin ilk 10 gününde, havaların daha soğuk olduğu döneminde yakılacak odun ve kömürün azalması, aynı zamanda hayvanların yemlerinin azaldığı durumlarda Hızır (a.s.) şerefine bayramın yapılması, onun yardımına olan ihtiyaçla alakalı olmuştur. İnsanlar her zaman başları sıkıştığında, zor durumda olduklarında boz atı Hızır'ı (a.s.) yardıma çağııır, o da yardımını insanlardan esirgemezdi. İnanışlara göre bayramda Hızır (a.s.) ve İlyas (a.s.) kendileri ile sıcak hava getirecek, az da olsa soğuk hava yerini ılık havayla değişmiş olacaktır. Bunu folklor örneklerinde de görmek mümkündür. 
Hızır, Hızır, Hızır İlyas,

Çıktı çiçek, oldu yaz (Nebiyev 1988b: 57). (Azerbaycan Türklerinde ilkbahar yaz olarak da bilinmektedir).

Bayram günü havanın kısmen de olsa güneşli olması karşıdan gelecek olan yılın bereketli olacağına işaret ederdi. İnanışlara göre, Hızır (a.s.) güneş ışığı ile yeryüzüne inerek insanlara bol, bereketli yıl getirir.

Nahçıvan bölgesinde bayram hazırlıkları birkaç gün önceden başlar, havaların soğuk olmasına rağmen evlerde temizlik yapılır, bahçeler süpürülüp temizlenir. İnanışlara göre Hızır (a.s.) temizlenmemiş ev ve bahçelere gelmez orayı bereketlendirmez. Aynı gün büyük küçük her kes yıkanır ve yeni elbiseler giyinirler. Bayramda çocuklara yeni elbiseler alınması âdeti de mevcuttur.

Hıdır-Nebi bayramında bayram alış verişinin yapılmasına, çerezlerin alınmasına büyük önem verilir. Bayramın sembolü kavrulmuş buğday, badem, ceviz, fındık, kenevir tohumu (kavrulmuş olarak satılıyor), küncüt, patlamış mısır, kuru üzüm, kestane, fıstık sayılıyor. Bütün çerezler ayrı ayrı olmak şartı ile tuzlu su ile ıslatıı. Islatılmış çerezler saclarda kavrularak sofra bezlerinin içine dökülür. Bütün çerezler soğuduktan sonra karıştırılarak tepsilere konulur. Halk inanışlarına göre bayramda buğday kavrulması gelecek yılın bereketli olması için yapılır. Diğer inanışa göre Hızır (a.s.) bütün evleri gezip dolaşır, buğday ve diğer çerezlerin kavrulmadığı evleri bereketlendirmeden geri döner. Bunun için de bayram günü bütün evlerde buğday kavrulmasına büyük önem verilir. Evinden cenaze çıkan aileler bile Hızır (a.s.)'ın memnun olması için bayram günü buğday kavururlar (Kaynak Kişi- K-4). Bayram günü kavrulan buğdaydan tavuklara, kuşlara, karıncalara pay verme âdeti de mevcuttur. İnanışlara göre bu uygulama eve gelecek olan hastalıkların önlenmesi için yapılmaktadır.

Nahcıvan bölgesinde kavrulan buğdaydan gavut yapılması âdeti de yaygındır. Aile büyükleri, dedeler ve ninelerin de Hıdır-Nebi buğdayından yemesi için kavrulmuş buğday el değirmeninde (dester olarak da bilinmektedir) öğütülerek gavut yapılır. Yaşılıar gavutu yemeden önce onu ılık ve az şekerli su veya süt ile ıslatarak hamur gibi yoğurur daha sonra onu ceviz büyüklüğünde yaparak tepsilere dizer, üstünü bir bezle kapatır ve çayla içerler. Yapılan gavut'tan komşulara dağıtma âdeti de vardır. Kuru gavut aynı zamanda dilek için de kullanılır. Bayram akşamı yatmadan önce dilek tutarak gavut'tan biraz alıp tabak veya tepsiye döker ve aralık bırakılan pencerenin önüne koyarlar. İnanışlara göre sabah gavut'ta Hızır'ın (a.s.) elinin veya asasını izi olursa dileğin gerçekleşeceğine inanırlar. Hıdır-Nebi buğdayından, çerezlerinden ve gavut'undan yemeyen birisinin sağlıklı olmayacağı inancı bölgede yaygındır. Bunun için de herkes Hızır Sofrasında olan yiyeceklerden yer. Benzeri inanç Anadolu Türkleri arasında da vardır. Hıdırellez bayramı başlamadan önce yaşlı kadınlardan birisi herkese bir fincan süt veya şeker dağıtır. Sütü içen ve şekeri yiyenlerin gelecek sene Hıdırellez'e kadar sağlıklı olacağına inanırlar (Kartal 1997: 276).

Nahçıvan bölgesinde bayram günü damat tarafından nişanlı kızlara, baba ocağından yeni evlenen kızlara bayram payı götürülmesi âdeti vardır. İnanışlarına göre nişanlı kızın gözü damadın ocağında, yeni evlenip baba ocağından ayrılan kızın gözü ise baba ocağında kalırdı. İnanışlara göre onları gözü yolda koymak iyi sayılmazdı. Bu 
sebepten dolayı bayram günü akşam olmadan nişanlı kızın ve yeni gelinin bayram payı götürülmeli idi. Gelecek olan misafirler için yemekler yapılır, sofralar kurulurdu. Bayram payının götürülmesi, kadınlar arasında olan bir uygulamadır. Erkekler bu misafirliğe katılmazdı. Götürülen bayram payının içinde gelin ve damat, aynı zamanda aile büyükleri için hediyeler olurdu. Bayram payı götürürken çerez tepsisinin hazırlanmasına özen gösterilirdi. Kavrulmuş çerezler şekerlemelerle, çöçelerle karıştırılarak yuvarlak tepsilere konulur, çevresine ise çeşitli meyvelerden dizilirdi. Üstü kırmızı renkli bezle kapatılarak gelin evine götürülürdü.

Nahçıvan'ın Cehriçay havzası ve ona yakın köylerinde ise (Cehri, Didivar, Buzgov, Payız köyleri) bunun aksine olarak nişanlı kızın veya yeni evlenen kızların aileleri tarafından damada bayramlık olarak bilinen "Hızır Payı" götürülmesi âdeti mevcuttur. İnanışlara göre Hızır (a.s.) erkektir bunun için de bayram erkeklere aittir (Gadirzade 2003:305). Tarihi çok eski dönemlere ait olan bu adet ve inanışlar halen de bölge halkı tarafından yaşatılmaktadır.

Nahçıvan bölgesinde Hıdır-Nebi bayramında uygulanan adet ve inançlar diğer bölgelere göre birçok bakımdan zenginlik göstermektedir. Meyve vermeyen ağaçların ve yumurtlamayan tavukların korkutulması âdeti sadece bölgeye özgüdür. Bayram günü sabah erkenden ev sahibi eline balta alıp meyve vermeyen ağacı keseceğini her kese duyurur. Ağacın altına giderek balta ile ağaca yavaştan vurmaya başlar ve yüksek sesle: "bu ağaç meyve vermediği için kesmek istiyorum bana yardım edecek biri var mı?" der. Çevrede olanlar ağacın yanına gelerek baltayı ev sahibinin elinden alıp yere bırakıp: "bu ağacı kesme, dibine Hıdır-Nebide kavrulan buğdaydan dök, dallarına kırmızı ve yeşil bez bağla meyve verecektir" derler. Ev sahibi yüzünü ağaca tutarak: "herkes şahit olsun bu sene de meyve vermezsen eğer seni seneye keseceğim ve tandırda yakacağım" der ve ağacın dallarına kırmızı ve yeşil bez bağlayıp, dibine HıdırNebi buğdayından dökerdi. İnanışlara göre yapılan bu uygulamadan sonra ağaç meyve verirdi (Kaynak Kişi-2).

Anlatılanlara göre yumurtlamayan tavukların korkutulması için, bayram günü sabah erkenden evin yaşı kadınlarından birisi tavukları çuvala toplayıp değirmene gitmek için yola çıkar. Yolda karşısına çıkan ilk kişi ona nereye gittiğini sorar. Yaşlı kadın cevabında: "Bu tavuklar yumurtlamıyorlar, bunları değirmene kesmeye götürüyorum" der. Karşılaştığı adam: "Bunları değirmene götür ama kesme, değirmenden buğday al Hıdır-Nebi bayramında kavrulmuş buğdayla karıştır sonra o buğdayları tavuklarına serp, tavuklar buğdayları yedikten birkaç gün sonra yumurta verecekler" der. Kadın karşılaştığı adamın dediği gibi yapar. Tavukları geri getirip bahçeye bırakıp, değirmenden aldığı buğday ile Hıdır-Nebi buğdayını karıştırarak tavuklara serperek:

Ben size Hıdır- Nebi ve değirmen buğdayı verdim,

Siz de bana Bayram yumurtası vereceksiniz- der (Kaynak Kişi-3).

Bayram yumurtası vereceksiniz dediği zaman Nevruz Bayramını kastetmiştir. (Hıdır- Nebi buğdayından, bereketin bol olması için ekin sahalarına serpilmesi âdeti de vardır). Nahçıvan bölgesinde bayram akşamı çocuklar kapılara giderek torbalar atar ve evlerden Hızır (a.s)'ın payını isterler. Akşam kapıya gelecek olan çocukların torbalarına 
koymak için evlerde yumurtalar boyanır, bayram çöçe'si (bir çeşit kurabiye) pişirilir. Bayramda yeşillik hamisi sayılan Hızır'ın (a.s.) şerefine yumurtaların yeşil boyanması ile ilgili bilgiler kaynaklarda da mevcuttur (Babayev 1988: 177). Anadolu Türklerinde de Hıdırellez bayramında soğan kabuğu ile yumurta boyanır ve "Hıdırellez yumurtası" olarak adlanır (Kartal 1997: 274).

Bayram herkesten çok çocukların sevincine sebep olur. Hava karardıktan sonra özellikle erkek çocuklar bir araya gelerek kapılara giderek torba atar evlerden 'Hızır'ın Payını" isterler. Gittikleri evlerde tanınmasınlar diye kapıyı çalar ve torbayı kapıya koyup kaçarlar. Kapıdan uzakta durup aşağıdaki şiiri söylerler.

Hızır'a- Hızır derler,

Hızır'ın payın verirler.

Hızır’a pay verenin oğlu,

Vermeyenin ikiz kızı olsun.

Ev sahipleri, çocukları sevindirmek için torbaya çeşitli çerezler, şekerlemeler ve boyanmış yumurtalar koyarak geri verirler. Çocuklar evlerden topladıkları yiyecekleri karıştırırlar ve daha sonra kendi aralarında bölüşürler. Eğlenceler geç saate kadar devam eder. Kapılara gidip torba atma âdeti sadece çocuklarla sınırlı kalmaz, yaşlılar da çok samimi oldukları ailelerin kapılarına giderek torba atarlar.

Bölgede nişanlı erkeklerin nişanlılarının evinin kapısından torba atması âdeti de mevcuttur. Bayram akşamı damat nişanlısının evinin kapısına giderek kapıyı iki kere çalar ve içinde horoz olan torbayı kapıdan içeri atar. Ev sahibi damadın kapıya geldiğini anlar "Hıdır Sofrası"nın yiyeceklerinden torbaya koyarak geri verir, horozu ise tavukların yanına bırakır (Gadirzade 2006: 13).

Nahçıvan'ın Culfa ilçesinin bazı köylerinde hayvanlarına vermeye otu samanı biten kişiler, ot samanı çok olan birinin kapısına gidip kapıdan içeri ipi atar. Ev sahibi kapıdan ip atan adamın durumunu anlar, bir, iki bağlam ot çıkarıp bahçenin dışarısına koyar. Derlenen bilgilere göre otu ve samanı biten kişi bütün köyü gezerek evlerden ot ve saman toplar, hayvanlarının ilkbahara çıkmasını sağlar. Tavuğu olmayanlar da bayram akşamı kapılara gider, evin bacasından veya kapısından içinde tavuk veya horoz kuyruğu olan torba atarlar. E v sahibi kapıya gelenin tavuk istediğini anlar, torbaya tavuk koyarak geri verir (Kaynak Kişi-5). Bayram günlerinde yapılan yardımlaşma ve dayanışmalar insanlar arası ilişkileri kuvvetlendirmiş aynı zamanda bayramı daha da eğlenceli hale getirir. Herkesin bayramı kutlaması için durumu iyi olanlar bayramdan bir gün önce bayram alış verişi yaparak hava karardıktan sonra fakirlerin kapılarına bırakırlar. İnanışlara göre bütün evlerde "Hızır Sofrası"nın bulunması, herkesin bayramı bir arada geçirmesi, karşıdan gelecek olan yılın bol bereketli olacağı gibi yorumlanır.

Bayramda yaşlı ninelerin saçlarına, genç kız-gelinin ve kız çocuklarının ellerine kına yakması âdeti bölgede yaygın olan bir uygulamadır. Bayram günü kına yakııması insanların bir sonraki Hıdır-Nebi bayramına kadar sağlıklı olacakları inancı ile alakalı olmuştur. Kınanın hazırlanacağı ev önceden belirlenir, herkes bir araya gelerek hem eğlenir hem de el ve saçlarına kına yakarlar. 
İnanışlara göre Hızır (a.s.) Hıdır-Nebi Bayramında gençlere nasip, evlere rızık dağıtır. Bayram günü insanlar ne kadar mutlu olursa Hızır (a.s.) da onlara mutlu oldukları kadar mutluluk verecektir. Bunun için de insanlar bayram gününün güzel geçmesi için kızlar-gelinler bir araya gelerek güzel sohbetler ederler, tatlılar ve yemekler yaparlar. Dileği olanların haşil pişirip yemesi âdeti bölgede yaygındır. (Haşil unla yapılan hamur yemeğidir. Özellikle yeni doğum yapan anneler tarafından tüketilen bir yemektir. Halk arasında kış yemeği, sıcaklık veren yemek olarak da bilinmektedir) Haşil piştikten sonra evde olan herkese dağıtılır. Dileği olan genç kızlar haşilin hepsini yemez, bir kaşık kadarını tabakta bırakırlar. Dilek tutup tabakta bırakılan haşili alıp bahçede meyve veren ağacın dallarından birinin üstüne koyup beklerler. Karga veya her hangi bir kuş haşili gagasına alıp uçarsa kızın evleneceğine, kuş haşili ağaç dalında yerse kızın bu sene de evlenmeyeceğine inanırlar. Benzer adet, Gagauz Türkleri arasında da uygulanmaktadır (Kalafat 2006: 137).

Dileği olan kızların tuzlu çöçe pişirmesi âdeti de bölgede yaygındır. Bol tuzlu pişirilen çöçeyi, dileği olan genç kızlar akşam yatmadan önce yer ama su içmezler. Gece rüyasında kendisine bir erkeğin su verdiğini görürlerse kısmetinin o şahıs olduğuna, kadının su verdiğini görürlerse onun akrabalarından birisi ile evleneceğine inanırlar (Nebiyev 1986a: 142).

Yukarıda Hızır (a.s.)'ın bayram akşamı gezerek insanlara rızık dağıttığından bahsedilmiştir. Evlerin rızkının çoğalması, aynı zamanda yiyeceklerin bereketlenmesi için gece pencerelerden biri aralık bırakılır. Hızır (a.s.) evlerine gelip gelmediğini bilmek için kadınlar pişirilmiş süte maya katmadan yoğurt yapar gibi kazanın üstünü bezle kapatırlar. Sabah erkenden baktıklarında süt yoğurt olursa Hızır (a.s.) eve gelip sütü mayaladığına ve evin rızkını bereketlendirdiğine inanılır.

Kars'a bağlı Sarıkamış bölgesinde ise Hıdırellez günü yiyeceklerinin bereketlenmesi için yiyeceklerin hepsinden biraz alıp torbaya koyarak meyvesi olan ağaca asarlar (Aydın 2006: 371).

Bayram günü Hızır (a.s.)'ın hastalara şifa dağıtması, onları iyileştirmesi ile ilgili bölgede yapılan bazı inanç ve uygulamalar mevcuttur. Nahçıvan'ın Şahbuz İlçesinin bazı köylerinde hasta olan kişilerin iyileşmesi için "kaşık atma" âdeti uygulanmaktadır. Bayram günü hasta olan kişiler dilek tutup kafalarının üzerinden arkalarına doğru ağaç kaşık atarlar. Kaşığın iç kısmı düşerse hastanın iyileşeceğine, arka tarafı düşerse hastanın uzun süren tedaviye ihtiyacı olduğuna inanılır. Kullanılan kaşık sonra suya akıtıır. İnanışlara göre kaşık suya akıtıldığında hastalık su ile akıp gidecek hasta iyileşecektir (Kaynak Kişi-6). Benzeri inanç ve uygulamalar Anadolu Türkleri arasında Hıdırellez günü yapılmaktadır. İnanışlara göre Hıdırellez günü Hızır (a.s.) güllü, çiçekli elbisesini giyinip kırlarda, bahçelerde gezecek, hastalara şifa dağıtacak, ayak bastığı yerlerde çiçekler açacaktır (Abdulla 1997: 11). Özellikle bazı hastalığı olanlar bayram günü yeşil otların üstünde dolaşarak iyileşeceklerine inanırlar. Hastaların dilek tutup ağaçlara ve çiçeklere bez bağlayıp Hızır (a.s.)'dan şifa dilemesi âdeti de mevcuttur (Abdulla 1997: 11). Hızır'ın (a.s.) hastalara şifa vermesi, sıkıntılı anlarda insanın imdadına yetişmesi ile ilgili bilgileri eski Türk Milli destanı olan "Kitabi- Dede Korkut'ta da görmekteyiz. "Dirse han oğlu Boğac Bey boyun"da Boğac yaralanınca boz atı Hızır (a.s.) onun yarasını üç kere eliyle okşayıp: "Sana bu yaradan, Korkma oğlan, ölüm 
yoktur, dağ çiçeği anan sütü sana merhemdir" dedi. (Kitabi Dede Korkut Destanı 1988: 39). Hızır (a.s.)ın kutsiyet taşıması, onun kurtarıcı rolü, ihtiyaç sahibine tam zamanında yetişip yardım etmesi inancı hala birçok halklar özellikle de Alevi- Bektaşi halklar arasında halen de yaşamaktadır. Hızır (a.s.)'ın temel işlevlerinden biri de felaket ve güç durumlarda imdada yetişip kurtarıcı rolü üstlenmesidir (Döğüş 2015: 89). İnanışlara göre Hızır (a.s.) darda olan birisinin gözüne yeşil elbiseli, yeşil sarıklı, aksakallı birisi olarak görünür, yardıma intiyacı olan kişiyi düştüğü durumdan kurtardıktan sonra çekip gider (Döğüş 2015: 90). Derlenmiş bilgilere göre herkes yaşam boyunca Hızır (a.s.)la üç kere karşılaşır, fakat insanlar Hızır (a.s.)'ı tanımazlar. Karşılaştığı zaman onu tanıyan insanların rızık ve bereketlerinin bol olduğuna inanırlar. Hızır (a.s.)ın kutsiyet taşıması inancı çok eski dönemlere ait olmakla beraber günümüzde de varlığını sürdürmektedir. Araştırmalar bayram günlerinde uygulanan adet ve inanışların insan hayatını kolaylaştırmak için yapıldığını göstermektedir.

Sonuç olarak söyleyebiliriz ki, Hızır (a.s.) ve İlyas (a.s.) la ilgili kutlanan bayram ve merasimler, bayram günlerinde uygulanan adet ve inanışlar Türk kültürünün ortak mirası olarak Azerbaycan Türkleri ile beraber diğer Türk halklarının yaşamında da önemli yere sahiptir. Tarihi İslamiyet'ten önceki dönemlere ait olan bu bayram kendinde bin yıllık adet ve inançları koruyarak günümüze kadar ulaştırmıştır. Atalarımızdan bizlere armağan edilen zengin kültür mirasına sahip çıkmalı bizden sonraki nesillerimize intikalini aktarmalı, yetişen genç neslin geçmişi bilmeleri ve geleceğe sağlam adımlarla yürümelerini sağlamalıyız.

\section{KAYNAKLAR}

ABDULLA, Gülten (1997), “Roman ve Türk Halkları'nın İlkyaz Şenlikleri”, V MTHKK Gelenek, Görenek, İnamlar Seksiyonu Bildirileri, Ankara, Kültür Bakanlığı Yayınları, 912.

AYDIN, Nurhan (2006), Her Yörüyle Sarıkamış, Erzurum: Okyanus Yayınevi.

Azerbaycan Mifoloji Metnler, (1988). Bakü: Elm Yayınevi.

BABAYEV, Tofig, (1998), El Ocaq Başına Yığışar, Bakı: Azerneşr Yayınevi.

DÖĞÜŞ, Selahattin, (2015), Anadolu'da Hızır-i̇lyas Kültü ve Hıdırellez Geleneği. Türk Kültürü ve Hacı Bektaş Veli Araştırmaları Dergisi. 2015/74, s. 77-100

GADIRZADE, Gadir, (2003), Aile ve Meişetle Bağlı Adetler, Inamlar, Etnogenetik Elaqeler, Bakü: Elm Yayınevi.

GADIRZADE, Türkan, (2006), İslamagederki Adetler, Inamlar ve Merasimler (Naxçıvan materialları esasında). Bakü: Nafta- Pres Yayınevi.

“KITABI DEDE KORKUT” Destanı. (1988), Bakü, Yazıçı Yayınevi.

KARTAL, Numan, (1997), Kocacıkta Hıdırellez Gelenekleri, V MTHKK Gelenek, Görenek, İnamlar Seksiyonu bildirileri. Ankara: Kültür Bakanlığı Yayınları, 272- 281.

KALAFAT, Yaşar, (2006), Balkanlardan Uluğ Türküstana Türk halk inançları (Tatarlar, Hakaslar, Kırqızlar, Boşnaklar, Acarlar, Edigeyler, Albanlar, Karaçaylar, Qreqoryanlar, Romanya, Şumnu- Burqaz, Gürcistan- Karaçöp, Kıbrıs, Rodas, Tacikistan, Suriye Türkleri). III-IV cilt. Ankara: Berikan Yayın 
NEBIYEV, Azad (1986). Neğmeler, İnanclar, Alqışlar. Bakü: Yazıcı Yayınevi

NEBIYEV. Azat (1988). El Neğmeleri, Xalq Oyunları. Bakü: Yazıcı Yayınevi

\section{Kaynak Kişiler}

KK- 1 Şirinova Besti, Nahçıvan Culfa İlçesi Kırna köyü, 1912 doğumlu, okuma yazması yok. (Görüşme 08.06.2006)

KK -2 Hüseynova Sura, Nahçıvan Kengerli İlçesi Hok köyü,1932 doğumlu, okuma yazması yok. (Görüşme 24.05.2007)

KK-3 Hüseynova Zehra, Nahçıvan Şahbuz İlçesi Şahbuz köyü, 1934 doğumlu, okuma yazması yok. (Görüşme 17.06.2006)

KK-4 Zeynalabddinova Gemer, Nahçıvan Ordubat İlçesi Tivi köyü, 1910 doğumlu, okuma yazması yok. (Görüşme 17.05.2007)

KK-5 İsmayıolva Gülçöhre, Nahçıvan Ordubat İlçesi Tivi köyü, 1951 doğumlu, (okuma yazması var). (Görüşme 17.05.2007)

KK-6 Orucova Zeyneb, Nahçıvan Şahbuz İlçesi Şahbuz köyü, 1945 doğumlu, (okuma yazması var). (Görüşme 03.06.2006) 